Instructions for authors, subscriptions and further details:

http://ijep.hipatiapress.com

\title{
Japanese and Korean Kindergartners' Perspectives of Play Using Photos
}

Satomi Izumi-Taylor, ${ }^{1}$ Yeonsun (Ellie) Ro, ${ }^{2}$ Jihee Han, ${ }^{3}$ Yoko Ito ${ }^{4}$

1) The University of Memphis

2) Institution of Early Global Education

3) Eui-Myung Kindergarten

4) Chiba University

Date of publication: February $24^{\text {th }}, 2017$

Edition period: February 2017 - June 2017

To cite this article: Izumi-Taylor, S., Ro, Y., Han, J., \& Yoko Ito. (2017). Japanese and Korean Kindergartners' Perspectives of Play Using Photos. International Journal of Educational Psychology, 6(1), 45-66. doi: 10.17583/ijep.2017.2049

To link this article: http://dx.doi.org/10.17583/ijep.2017.2049

\section{PLEASE SCROLL DOWN FOR ARTICLE}

The terms and conditions of use are related to the Open Journal System and to Creative Commons Attribution License (CC-BY). 


\section{Japanese and Korean Kindergartners' Perspectives of Play Using Photos}

Satomi Izumi-Taylor

The University of Memphis

Jihee Han

Eui-Myung Kindergarten
Yeonsun (Ellie) Ro

Institution of Early Global Education

Yoko Ito

Chiba University

\section{Abstract}

The purpose of the study was to examine Japanese and Korean kindergarteners' perspectives by asking them to photograph play and explain why their photos represent play (photo elicitation interviews). The participants consisted of 50 kindergarteners on Japan's main island and 50 kindergarteners in South Korea. Japanese and Korean kindergartners were provided with digital cameras and were asked to photograph their views of play without adult accompaniment. Afterwards, the children were asked to describe why their photos represented play. "Can you tell me why this means play to you?" The data were analyzed using content and thematic analyses and the photos were reviewed along with children's responses. The thematic analysis of results revealed that Japanese and Korean kindergartners' perceptions were related to interactions with other children, pretend play, schoolyards, and toys or props. The findings of this study indicated the ways in which Japanese and Korean children's play perceptions were related to cultural and social contexts. Implications for early childhood education were also discussed.

Keywords: Japanese and Korean children's views of play, photo elicitation interviews with Japanese and Korean children, comparative study 


\section{Perspectivas sobre el Juego en Infantil de Niños y Niñas Japoneses y Coreanos}

Satomi Izumi-Taylor

The University of Memphis

Jihee Han

Eui-Myung Kindergarten

\author{
Yeonsun (Ellie) Ro \\ Institution of Early Global Education \\ Yoko Ito \\ Chiba University
}

\section{Resumen}

El objetivo del estudio fue examinar las perspectivas de los niños japoneses y coreanos de educación infantil pidiéndoles que fotografiaran y explicaran por qué sus fotos representan el juego (entrevistas de elicitación fotográfica). Los participantes consistieron en 50 niños de la isla principal de Japón y 50 de Corea del Sur. Los niños de educación infantil japoneses y coreanos recibieron cámaras digitales y se les pidió que fotografiaran sus puntos de vista del juego sin acompañamiento de adultos. Posteriormente, se pidió a los niños que describieran por qué representaban sus fotos. "¿Puedes decirme por qué esto significa para ti jugar?" Los datos fueron analizados mediante análisis de contenido y temáticos y las fotos fueron revisadas junto con las respuestas de los niños. El análisis temático de los resultados reveló que las percepciones de los niños japoneses y coreanos estaban relacionadas con las interacciones con otros niños, juegos de simulación, patios escolares y juguetes o accesorios. Los hallazgos de este estudio indicaron las maneras en que las percepciones de juego de niños japoneses y coreanos estaban relacionadas con contextos culturales y sociales. También se discutieron las implicaciones para la educación de la primera infancia.

Palabras clave: Perspectivas sobre el juego en niños japoneses y coreanos, entrevistas estimuladas con fotgrafías, estudio comparativo 
onsider the following humorous phrases by Japanese and Korean kindergartners when asked to take pictures and describe why they considered it to be play: "I photographed this chicken's egg because when we take care of the chickens, we can keep their eggs," "I love this space between these two buildings," "Boys are making something with blocks," and "Because someone folds paper to make something that flies."

Although adults are familiar with their own play perspectives, we know little of children's (Izumi-Taylor, Ito, \& Krisell, 2016). What constitutes play for adults might not be the same for children. Play is defined as behavior that leads to all phases of development within the cultural context in which players interact (Kieff \& Casbergue, 2000). Many educators agree that "Play is an important vehicle for developing self-regulation as well as for promoting language, cognition, and social competence" (Copple \& Bredekamp, 2009, p. 14). Yet, we debate about what are the best practices in early childhood education when teachers are required to implement academic curricula (National Council of Accreditation for Teacher Education, 2014; Russell, 2011). Teachers have some trepidation about focusing on only standardized test scores (Follari, 2011) and lack the time and training to provide developmentally appropriate play activities (DeVries, Zan, Hildebrant, Edmiaston, \& Sales, 2002). When teachers adhere only to slogans that play is the best way for children to learn, a shallow understanding may lead to implementing play-oriented curricula that may be "nothing more than entertainment" (DeVries et al., 2002, p. 6). Teachers can offer appropriate play activities when given clear and detailed descriptions of such.

Because much of American research on early childcare in the past two decades has been conducted on "middle class, European American families" (Johnson, Jaeger, Randolph, Cause, Ward \& National Institute of Child Health and Human Development Early Child Care Research Network, 2003, p. 1227), studying children's play perspectives in two Asian countries might provide more universal views. As children's notions of play are culturally related (Izumi-Taylor, Ito, \& Krisell, 2016), their values and attitudes might also influence their perceptions. In spite of cultural, educational, and political differences, early childhood educators in Japan and Korea recognize 
play as fundamental (Izumi-Taylor \& Ro, 2016); however, Japanese children's views of play might differ from those of Korean children.

As there is a growing global focus on child-centered education and care (Roopnarine, 2015), examining children's views of play in Japan and Korea might provide a universal understanding of "global issues of meeting the culturally, developmentally appropriate needs of young children" (Roopnarine, 2015, p. 1). Through such examination, we can better prepare teachers to work with children and families from diverse cultural backgrounds. Identifying and examining similarities and differences in children's views of play in different cultures assists scholars and educators in improving their own childcare practices.

\section{The Purpose of the Study}

The purpose of the study was to examine Japanese and Korean kindergarteners' perspectives by asking them to photograph play and explain why their photos represent play (photo elicitation interviews). Because young children have difficulty verbally expressing themselves (Einarsdotti, 2005; Pink, 2013; Thompson \& Williams, 2009), through photo elicitation interviews (PEIs) (Phelan \& Kinsella, 2011; Pink, 2013; Thompson \& Williams, 2009), they can reveal their perspectives. Photography can support children's explanations of school activities (Ching, Wang, Shih, \& Kedem, 2006; Clark-Ibanez, 2004; DeMarie, 2001; DeMarie \& Ethridge, 2006; Kirova \& Emme, 2009).

Finding out a children's views of play as they actively participate in it would provide important sources for educators and others involved in children's lives (Ramazan, Ozdemir, \& Beceren, 2012). There exists limited and outdated research on children's perceptions of play in different cultures (Izumi-Taylor, Ito, \& Krisell, 2016). For these reasons, this study was conducted to address such limitations, guided by these research questions: 1 . What views are revealed in Japanese and Korean kindergartners' photos of play? And 2. Are there any similarities or differences among their views? If so, how are they similar or different? This paper first outlines the contexts concerning previous studies of children's views of play and PEIs, early childhood education and play in Japan and Korea, and is followed by a 
report on the study, analysis of findings, and discussions of implications and limitations for early childhood education.

\section{Previous Studies of Children's Views of Play and PEIs}

Generally, children's favorite activity at school was play, and they enjoyed selecting their own play activities (Wiltz \& Klein, 2001). Children's perceptions of play were related to games, mini-gyms, and playing with other children (Fivush, 1984). Young children viewed school as work, and recess as play (Dockett, 2002). Kindergartners and first/second graders preferred play over work (Wing, 1995), and child-initiated play was considered play, while teacher-initiated activities were viewed as work (Cooney, Gupton, \& O’Laughlin, 2000; Cunningham \& Weigel, 1992). Dockett and Meckley (2007) found that American and Australian children said playing with friends was important, and they enjoyed recreational play but disliked teachers' involvement. Children's views and experiences at a schoolyard in Greece were examined through interviews and drawings, and it was found that children enjoyed "strolling around and talking with friends as their favorite activity in the school ground" (Christidou, Tsevreni, Epitropou, \& Kittas, 2013, p. 71).

These studies mentioned above examined children's perspectives of play through interviews, but young children often found it difficult to verbally express their views, and their responses could have been limited (IzumiTaylor, Ito, \& Krisell, 2016). To address such limitations, asking them to photograph their views of play might provide opportunities to express their meanings freely (Izumi-Taylor et al., 2016; Phelan \& Kinsella, 2011). Through this method, children were empowered (Izumi-Taylor et al., 2016), and photographing their play could help us understand children's definitions of it. As many teachers report having difficulties in offering children creative play activities (Levin, 2013), awareness of children's play perspectives could assist in offering quality play experiences.

Photography can represent children's meanings of their activities (DeMarie, 2001; DeMarie \& Ethridge, 2006; Einarsdottir, 2005; Kumpulainen, Lipponen, Hilppo, \& Mikkola, 2013; Sairanen \& Kumpulainen, 2014). When asked to photograph people or things with 


\section{Izumi-Taylor et al.-Kindergartners' Perspectives of Play}

"social attachments and meaning" to explain their lives, children photographed their play interactions with others (Clark-Ibanez, 2004). Asking them to take photos to express the meaning of their lives can provide us with authentic understanding of their perceptions (Byrnes \& Wasik, 2009; DeMarie \& Ethridge, 2006; Kumpulainen et al., 2013). A study examining Italian children's perceptions of a park through photography (Gandini, 2012) found that children were capable of showing their ideal "green areas in their courtyards," and they preferred playing with friends (p. 3). "Children were quite interested in the depth and distance of the landscape and the absence of obstacles like walls and bushes" (Gandini, 2012, p. 7). Children's perspectives of school lives in Iceland through photography revealed they enjoyed taking pictures and using them to communicate their thinking with others (Einarsdottir, 2005). In this study children's photographs were influenced by accompanying adults, and when they freely took pictures with no adults present, they took unique pictures, including "bathrooms, hallways, and cubbies" where they could wander and explore.

When Izumi-Taylor and her colleges (2016) asked both American and Japanese kindergartners to take pictures and explain their views of play, a majority photographed outdoor play with other children. It was found that both American and Japanese children's play perspectives were related to interactions with others, preferred environments, and favorite toys/props. Only Japanese children took photos of toys/props without people, but this was not the case for American children. When asked to explain their pictures, many American and Japanese children described the content. There are no studies of children's views of play in Japan, but one study utilizing children's photos revealed photography was an effective tool to understand how children can express their meaning of life when photographing favorite items, current interests, and memorable events (Oishi, 2010). Another Japanese study (Teramoto \& Ohnishi, 1995) examined elementary and junior high school students' concepts of schools, asking them to photograph their environments using PEIs. Students photographed schoolyards where they enjoyed playing and communicating with others. There exists no study of Korean children's perceptions of play. 


\section{Japanese and Korean early Childhood Education and Play}

In Japan, the National Curriculum Standards for Kindergarten (the Course of Study for Kindergarten) set forth by the government describe how play promotes children's learning and developing balanced minds and bodies (The Ministry of Education, Culture, Sports, Science, and Technology, 2008). Japanese early childhood education curricula are based on specific guidelines that mandate play-centered education in group-oriented environments (Izumi-Taylor \& Ro, 2016). Children-initiated play is highly valued, and adults need not force participation in play activities. Teachers generally support children's play based on the cultural belief that play should be valued for itself rather than how it promotes children's education (Izumi-Taylor \& Ro, 2016). Teachers must support and facilitate such activities for children. To encourage engagement in play, teachers should focus on cultivating children's spirit of inquiry, interests, abilities to relate positively with their environments, capacities to innovate, and abilities to solve problems.

In Korea, the National Common Curriculum Standards set forth by the government emphasize "child-centered and play-based curricula" as play is one of the best ways to enhance children's creativity, development and learning (KICCE, 2013, p. 3). Kindergartens follow a national curriculum entitled the Nuri curriculum (Park, Jang, \& Park, 2016) which describes five primary domains of early childhood education: physical activity and health; communication; social interactions; art experiences; and nature exploration (Ministry of Education, 2015). The philosophy of the Nuri curriculum delineates that any activity in preschools and kindergartens should promote these five areas, and play-oriented educational activities are encouraged. Korean kindergarten teachers need to integrate play into curricula rather than just providing activities, and allowing children ample time to explore and experience the world in carefully designed educational and playful settings is important (KICCE). Early childhood educators are expected to offer various kinds of pretend play settings, including banks, restaurants, and libraries in order for children to experience preparation for real-life (Izumi-Taylor \& Ro, 2016). 


\section{Izumi-Taylor et al.-Kindergartners' Perspectives of Play}

One study conducted in Korea revealed that the word, play, was used in conjunction with activities in order to diminish the negative image of play being interpreted as only playing (Park \& Park, 2014). In the Nuri curriculum guideline, many different kinds of play are introduced, including traditional Korean cultural play, group and individual play, pretend play, and play in nature (Ministry of Education, 2015). The Nuri curriculum handbook presents a new direction toward multicultural education for young learners to become global citizens (Hoot, Bakuza, Lavasani, Park, Sharifian, \& Szecsi, 2015).

\section{Method}

\section{Participants}

The participants consisted of 50 kindergarteners (five year olds) on Japan's main island, and 50 kindergarteners (five year olds) in South Korea. The respondent pool was selected through convenience of access and availability (Hancock \& Algozzine, 2006). Our respondent pool was children who "may have the best information with which to address the study's research questions" (Hancock \& Algozzine, 2006, p. 40). School directors informed parents that children's participation was voluntary, and not participating would not negatively affect them. Children aged three to five attended Japanese preschools called kindergartens (Izumi-Taylor, 2013). The Japanese school in the study served children from middle-class families and were close to playgrounds, and all children were Japanese. This school valued play, and the children engaged in group-oriented activities. The Korean kindergarten served children from middle-class families. The playground is attached to the building, and all children were Korean. Play was valued at this school, and the children often engaged in both individualand group-oriented activities.

\section{Data Collection}

The fourth author collected the Japanese data, and the third author collected the Korean data. Both authors provided Japanese and Korean 
kindergarteners with digital cameras and asked them to photograph their views of play without adult accompaniment. We requested two photos from each child, some taking only one, others taking two. Japanese children took more photos than their Korean counterparts. Afterwards, these authors showed their photos to children and asked to describe why the photos represented play, by asking "Can you tell me why did this means play to you?"

\section{Data Analysis}

The first author translated Japanese children's responses into English; two Japanese bilingual educators reviewed the responses and agreed on translation (Izumi-Taylor, Ito, \& Gibbons, 2010). The second author followed the same procedures. We analyzed the data using content and thematic analyses and reviewed the photos combined with children's responses as Ray and Smith recommended (2011). "We counted the number of people, items, toys/props, and buildings in each photo" (Izumi-Taylor, Ito, \& Krisell, 2016, p.4). Children's responses were categorized by following Fivush's (1984) coding ("descriptions of the physical environments," "descriptions of an affective state" (p. 1700), descriptions of pretend play and of toys and props, and descriptions of others' talents/skills).

Authors defined the descriptions of photos using children's explanations, such as, "This is my teacher" or "Children are running." Descriptions of the physical environments included, "Children are playing in the hospital, and it looks messy" or "When the sun shines on our forest, we see birds." Affective state referred to such statements as "They are playing together. They are my friends, "or "Children are moving pleasantly." Descriptions of pretend play included: "Four year olds are working at the ice cream store," and "Children are pretending to be anchors on TV." Descriptions of toys or props included, "We play with this toy all the time," or "I love the jungle gym the best." Descriptions of others' talents/skills included: "This child makes cool toys with pine cones," or "This girl can do many tricks on the monkey bars."

"According to its relevance to the study, multiple category codings were counted as separate responses" (Izumi-Taylor, Ito, \& Gibbons, 2010, p. 412) 


\section{Izumi-Taylor et al.-Kindergartners' Perspectives of Play}

because some children gave the same explanations for their photos. Irrelevant responses, such as "This is my photo" was discarded, and some responses were coded more than once.

\section{Results}

Table 1 indicated we counted the contents of each photo, including people, items, toys/props, life forms (chickens and an ant), buildings, and pictures taken outdoors and indoors. Japanese children took photos outdoors (44\%), while Korean children took $28 \%$ of outdoor photos. Korean children took $96 \%$ of photos with people, compared to $30 \%$ by the Japanese. Korean children took $70 \%$ of indoor photos, compared to $22 \%$ by the Japanese. Only Japanese children (26\%) photographed school buildings and chicken coops. Both Japanese and Korean children captured $28 \%$ of pictures of their schoolyards.

Table 1

Content of photos

\begin{tabular}{lcc}
\hline & Japanese children & Korean children \\
\hline people & $30 \%$ & $96 \%$ \\
Outdoors & $44 \%$ & $28 \%$ \\
indoors & $22 \%$ & $70 \%$ \\
school & $26 \%$ & $0 \%$ \\
buildings/chicken & & \\
coops & & \\
Schoolyard & $28 \%$ & $28 \%$ \\
toys/props & $88 \%$ & $52 \%$ \\
life forms only & $8 \%$ & $2 \%$ \\
\hline
\end{tabular}

Qualitative analysis of the data regarding the reasons behind their pictures indicated four themes of children's views of play: interactions with others, pretend play, schoolyards, and toys/props. Each theme was defined as follows: interactions with others refer to children engaging in some activity with others, pretend play is defined as children acting out life situations, schoolyards represent places where children engage in outdoor activities, 
and toys/props include materials, items, and equipment. Table 2 delineated how each response was categorized using some items from Fivush's coding (1984), and we discussed our themes accordingly.

Table 2

Children's reasons for taking photos

\begin{tabular}{|c|c|c|}
\hline & Japanese children & Korean children \\
\hline 1. Descriptions of the photos & $88 \%$ & $100 \%$ \\
\hline $\begin{array}{l}\text { 2. Descriptions of physical } \\
\text { environments }\end{array}$ & $34 \%$ & $10 \%$ \\
\hline $\begin{array}{l}\text { 3. Descriptions of an affective } \\
\text { state }\end{array}$ & $34 \%$ & $8 \%$ \\
\hline 4. Descriptions of toys/props & $84 \%$ & $56 \%$ \\
\hline $\begin{array}{l}\text { 5. Descriptions of others' } \\
\text { talents/skills }\end{array}$ & $12 \%$ & $0 \%$ \\
\hline 6. Descriptions of pretend play & $14 \%$ & $22 \%$ \\
\hline
\end{tabular}

\section{Interactions with Others}

Thirty percent of Japanese and 96\% of Korean children captured photos of children interacting with others, and eight $\%$ of Japanese children's photos contained their teachers while six $\%$ of Korean children included their teachers in their photos. One Korean girl explained her photo, "Children are laughing and singing in a duet." Another girl said, "They are drawing and making something." Two Japanese boys described their pictures thusly, "I photographed everyone playing soccer together," and "I took this because they seemed to be happy." Only Japanese children used the word, friends, to explain their photos suggesting an affective state: "My teacher and my friend are talking to each other," explained one girl. A boy said, "My friends are playing together. They are good to each other."

Regarding these children's photos, many of their reasons were related to descriptions of what children were doing. One Japanese boy who captured two boys on the grass smiling at each other said, I photographed them because they appeared to be enjoying each other's company." One Korean 


\section{Izumi-Taylor et al--Kindergartners' Perspectives of Play}

girl described her photo of children engaging in movement activities, "Children are moving pleasantly." These comments appeared to be associated with both descriptions of photos and an affective state.

Interestingly, only Japanese children's explanations indicated that they seemed familiar with their peers' talents/skills. One boy described his photo of a child working at a table, "This child is very good with his hands and makes pretty pine cone decorations." One girl praised others on a structure by saying, "This is where you can do rope tricks. They are good at this."

\section{Pretend Play}

Korean children $(22 \%)$ photographed more pretend play than their Japanese counterparts (14\%). Two Korean girls' explanations included, "It looks like they are playing on the airplane," and "They are wearing chefs' clothes, getting ready to cook." Two Japanese girls told us: "Four year olds are pretending to run an ice cream store," and "These girls are playing mothers." These children's explanations were related to the descriptions of their photos.

Out of $14 \%$ of such Japanese photos, the majority of children engaged in pretend play in the schoolyard, and $22 \%$ of Korean children's photos were taken indoors. It appeared to show Japanese children's preference for schoolyard play and Korean children's preference for indoor play.

\section{Schoolyards}

Fourteen percent of both Japanese and Korean children's photos were of the schoolyards. Some Japanese photos contained only the schoolyard sans people, while their Korean counterparts took only $2 \%$ of such photos. Again, a strong preference for schoolyard play by Japanese children was evident. Thirty-four percent of Japanese and $10 \%$ of Korean children's descriptions of photos were related to physical environments. One Japanese girl photographed a building in her schoolyard and she explained, "We play many different things in this building," and one boy described his photo of the schoolyard, "We are digging a hole so we can build our new fort here." One Korean girl's photo captured many children playing with boats at a 
small pond in the schoolyard and she claimed, "Children are playing with boats. They are watching boats floating." Another girl's photo captured children on a structure and explained, "They are climbing."

Some Japanese children's explanations of photos were related to an affective state and were associated with nature in the schoolyard. One girl photographed one of the flower gardens in the schoolyard and she opined, "I love this place. Don't you think leaves are pretty?" Another girl captured the schoolyard connected to a small forest, saying "Isn't this place beautiful? The sun is reflecting on trees." One Japanese boy who appeared to be enamored with trains photographed trains traveling a long distance from the schoolyard said, "When I come here, I can see trains going by way over there. I love to watch trains from here." No Korean children took such photos.

\section{Toys/Props}

Eighty-four percent of Japanese and $56 \%$ of Korean children's photos contained toys/props. One Japanese girl photographed only the jungle gym with no one on it saying, "I love this jungle gym best!" Her statement indicated both the descriptions of photos and an affective state. A Japanese boy took a photo of one ball of dirt in a bucket with a spoon with no people around and proudly said, "I created this dirt ball." His explanation was related to descriptions of the photos. One Korean boy captured others in the block center and explained, "Boys are making something with blocks." Another boy's picture contained children playing with toys on the floor and said, "Toys are here and there." These Korean boys described the contents of their photos. Interestingly, many Japanese children photographed toys/props without people while the majority of Korean children's pictures included someone.

As shown in Table 1, 8\% of Japanese and 2\% of Korean children captured life forms including chickens and an ant. The chickens were in coops at the schoolyard, and some of children's explanations included: "This is an overweight chicken," or "I like chickens. When we take care of them, we can keep their eggs." One Korean girl pointing to an ant on the 
schoolyard said, "An ant is moving." All these photos contained just chickens and an ant without people.

\section{Discussion}

The thematic analysis of results reveals how Japanese and Korean kindergartners view play. Their perceptions are related to interactions with other children, pretend play, schoolyards, and toys or props. The following discussion addresses the previous two research questions simultaneously.

\section{Japanese and Korean Kindergartners' Views of Play}

Similarities and Differences: Both Japanese and Korean children freely photographed their views of play and provided reasons for the photos. Korean children took more photos indoors than outdoors, compared to their Japanese counterparts. The fact that Japanese children photographed more outdoor play than their Korean counterparts might be related to the school environments that provide nature and living life forms such as chickens to nurture children's love and respect for natural environments (The Ministry of Education, Culture, Sports, Science, and Technology, 2008). Japanese early childhood teachers are expected to support children's minds and bodies in nature. The reasons that Korean children's photos were focused on indoor play might be partially explained by the school's indoor environments that provided many pretend play props, including a stage, airplane, kitchen, fire station, gas station, hospital, and a TV station, etc. (Ministry of Education, 2015). More Korean children's photos captured people than those of the Japanese.

Both Japanese and Korean children's pictures captured their interactions with others, and their reasons for taking such photos coincided with their descriptions of them. These observations were congruent with Fivush's study (1984) that children think it is play if they play with others. DeMarie's study revealed that American preschoolers' photos showed interaction with others when photographing zoo animals (2001). Children are more likely to consider it as play when interacting with others (Christidou et al., 2013; 
Dockett \& Meckley, 2007; Izumi-Taylor et al., 2016; Ramazan et al., 2012). Likewise, Japanese children photographed their preferred play environments where interacting with their peers (Teramoto \& Ohnishi, 1995). When asked to photograph their lives, American children took photos of play with others (Clark-Ibanez, 2004).

Although both Japanese and Korean children photographed pretend play, Japanese children preferred to capture their pretend play in natural outdoor settings, while Korean children's photos were taken in indoor play settings pre-designed by teachers. Again, Japanese children's preference for outdoor play environments was evident. This Japanese preference was further supported by a study (Izumi-Taylor, Ito, \& Krisell, 2016) that Japanese children took more outdoor play photos than their American counterparts.

In line with Korean children's preference for indoor play, their photos of indoor activities might be related to the notion that based on Korean cultural and educational expectations, teachers are trained to be skillful in setting up indoor props that are diverse, and pretend play is one of the highly recommended play methods for teaching young children (Ministry of Education, 2015).

Although both Japanese and Korean children took the same number of photos of schoolyards, more Japanese children captured such photos without people but included flowers, trees, chicken coops, and frosty playgrounds. Some Japanese and Korean children photographed life forms such as chickens and an ant without people. According to DeMarie, children have a tendency to photograph familiar and important things in preschool environments (2001). When asked to photograph their views of school, many young children photographed playgrounds, and some took pictures of familiar living forms (Christidou et al., 2013; Einarsdotti, 2005; DeMarie, 2001; Izumi-Taylor et al., 2016; Kumpulainen et al., 2013).

These Japanese children appeared to be sensitized to their natural surroundings, and some reasons for taking such photos were related to their feelings. Similarly, a study of American and Japanese children's perceptions of play (Izumi-Taylor, Ito, \& Krisell, 2016) revealed that more Japanese children related their views of play to natural outdoor settings than their American counterparts. These Japanese children's views of play might be partially influenced by their culture as the Japanese teachers in this study 


\section{Izumi-Taylor et al.-Kindergartners' Perspectives of Play}

provided natural environments where children can appreciate flowers, trees, chickens, and frosty playgrounds. Japanese children must experience nature to develop rich emotions and to understand how to care for living things through play (The Ministry of Education, Culture, Sports, Science, and Technology, 2008). Additionally, some Japanese children's photos captured the depth and distance of the schoolyard and appeared to show their interests in walls, bushes, trains, chicken coops, bathrooms, forts, and play structures sans people. These observations were further corroborated by others (Einarsdotti, 2005; Gandini, 2012) claiming that given opportunities, children tended to be interested in various areas in schoolyards where they can explore and wander, and they were able to see objects/items beyond the schoolyard.

While both Japanese and Korean children included toys/props in their photos, Japanese children's explanations were more associated with emotions and interests than their Korean counterparts. Japanese educational guidelines (Ministry of Education, Culture, Sports, Science, and Technology, 2008) clearly state that teachers must support children's abilities to care for their environments, including taking care of their play materials. Contrarily, Korean children's explanations of such were related to how children were engaging in pretend play settings with others. Again, Korean children's preference for interacting with others during play was evident. It appeared that because Korean teachers are required to provide children opportunities to engage with various kinds of pretend play materials in group settings, these children's explanations were influenced by their environments (Izumi-Taylor \& Ro, 2016; Ministry of Education, 2015). Through such environments, teachers aim to develop children's social skills and to enact real-life situations.

\section{Implications and Limitations}

Although it might be difficult to draw a conclusion from children's photos of play to understand teachers' attitudes about play, each of the themes that emerged from the data could provide an insight and reflection for teachers. The findings of this study indicate the ways in which Japanese and Korean 
children's play perceptions are related to their cultural and social contexts. With new teaching methods significantly impacting on the potential of teachers to connect around the globe, educators in different cultural contexts might work together to expand their understanding of children's views of play. As part of this collaboration, teachers could also observe the effective methods to create educational materials and effective play environments. By doing so, teachers from different nations can understand how they can better assess the play-related activities in their own classrooms by including everyone involved in children's education. Teachers might provide space to understand and to appreciate the different views of play held by young children, through open debate about play in both general and applied contexts.

In the process of collaboration, teachers can examine how children see play and what is the best way to provide appropriate play activities. By understanding and appreciating each country's children's similar and different views of play, teachers can integrate appropriate play activities in the classroom.

When everyone involved in young children's care and education respects and values different perspectives of play held by children in our world, it helps educators to understand how to create play environments that are based on children's interests and needs because play appears to serve as a vehicle to unify and integrate all dimensions of learning and development. Educators need to fully realize and listen to children's voices. One way to do this is through PEIs. Through PEIs, adults can listen and understand children's opinions and views of school activities.

The results of this study must be considered limited given the size and particularity of the two samples from middle-class-families, and children from different class families should be included to better understand their views of play. Additionally, some Japanese children took more photos than their Korean counterparts that could have influenced our interpretations of children's views of play. 
62 Izumi-Taylor et al.-Kindergartners' Perspectives of Play

\section{References}

Byrnes, J., \& Wasik, B. (2009). Picture this: using photography as a learning tool in early childhood classrooms. Childhood Education, 85(4), 243248. doi:10.1080/00094056.2009.10523090

Ching, C., Wang, X., Shih, M., \& Kedem, Y. (2006). Digital photography and journals in a kindergarten-first-grade classroom: Toward meaningful technology integration in early childhood education, Early Education and Development, 17(3), 347-371.

doi:10.1207/s15566935eed1703 3

Christidou, V., Tseverni, I., Epitropou, M., \& Kittas, C. (2013). Exploring primary children's views and experiences of the school ground: The care of a Greek school. International Journal of Environmental \& Science Education, 8(1), 59-83.

Clark-Ibanez, M. (2004). Framing the social world with photo-elicitation interviews. American Behavior Scientists, 47(12), 1507-1526. doi: $10.1177 / 0002764204266236$

Cooney, M., Gupton, P., \& O'Laughlin, M. (2000). Blurring the lines of play and work to create blended classroom learning experiences. Early Childhood Education Journal, 27(3), 165-171. doi:10.1007/BF02694230

Copple, C., \& Bredekamp, S. (2009). Developmentally appropriate practice in early childhood programs serving children from birth through age 8 (3rd Ed.). Washington, DC: NAEYC.

Cunningham, B., \& Weigel, J. (1992). Preschool work and play activities: Child and teacher perspectives. Play and Culture, 5, 92-99.

DeMarie, D. (2001). A trip to the zoo: Children's words and photographs. Retried from: http://ercp.uiuc.edu/v3n1/demarie.html

DeMarie, D., \& Ethridge, E. (2006). Children's images of preschool: The power of photography. Young Children, 61(1), 101-104.

DeVries, R., Zan, R., Hildebrandt, C., Edmiaston, R., \& Sales, C. (2002). Developing constructivist early childhood curriculum. New York: Teachers College Press.

Dockett, S. (2002). Teachers don't play! Children's views of play at school. Play and Folklore, 42, 9-12. 
Dockett, S., \& MecKely, A. (2007). What young children say about play at school: Unites States and Australian comparisons. In D. Sluss, \& O. Jarrett. (Eds.), Play and Culture Studies (pp. 88-113). Lanham, MD: University Press of America.

Einarsdottir, J. (2005). Playschool in pictures: children's photographs as a research method. Early Child Development and Care, 175(6), 523541. doi:10.1080/03004430500131320

Fivush, R. (1984). Learning about school: The development of kindergartners' school scripts. Child Development, 55(5), 1697-1709.

Follari, L. (2011). Foundations and best practices in early childhood education: History, theories, and approaches to learning. Upper Saddle River, NJ: Pearson Education Inc.

Gandini, L. (2012). Imagining, designing, constructing and living in the park of the Martiri di Sesso preschool. Innovations in Early Education, the International Reggio Exchange, 19(3), 1-14.

Hancock, D., \& Algozzine, B. (2006). Doing case study research. New York, NY: Teachers College Press.

Hoot, J. L., Bakuza, F. R., Lavasani, M. G., Park, S. R., Sharifian, M. S., \& Szecsi, T. (2015). International Perspectives on Early Childhood Teacher Education. In L. Couse, \& S. Recchia (Eds.), Handbook of Early Childhood Teacher Education (pp. 348-363). Abingdon, UK: Routledge.

Izumi-Taylor, S. (2013). Scaffolding in group-oriented Japanese preschools. Young Children, 68(1), 70-75.

Izumi-Taylor, S., Ito, Y., \& Gibbons, A. (2010). Early childhood pre-service teachers' perceptions of teaching technology to children in Japan and the United States. Research in Comparative and International Education, 5(4), 408-420. doi:10.2304/rcie.2010.5.4.408

Izumi-Taylor, Ito, Y., Krisell, M. (2016). American and Japanese kindergarteners' views of play through the use of photo elicitation interviews (PEIs). Research in Comparative and International Education. doi:10.1177/17454999/6663379

Izumi-Taylor, S., \& Ro, Y. (2016). Japanese and Koran children's ideas of play through photo elicitation interviews (PEIs). Poster presented at the National Association for the Education of Young Children. Anaheim, CA. 
Johnson, D., Jaeger, S., Randolph, M., Cauce, A., Ward, and National Institute of Child Health and Human Development Early Child Care Research Network. (2003). Studying the effects of early child care experiences on the development of children of color in the United States: Toward a more inclusive research agenda. Child Development,74(5), 1227-1244.

Keiff, J., \& Casbergue, R. (2000). Playful learning and teaching: Integrating play into pre school and primary program. Needham Heights, MA: Allyn \& Bacon.

KICCE: Korean Institute of Child Care and Education (2013). Policy brief: Nuri curriculum ( $\left.2^{\text {nd }} E d s.\right)$. Seoul, Korea: KICCE.

Kirova, A., \& Emme, M. (2009). Immigrant children's bodily engagement in accessing their lived experiences of immigration: Creating poly-media descriptive texts. Phenomenology \& Practice, 3(1), 59-79.

Kumpulainen, K., Lipponen, L., Hilppo, J., \& Mikkola, A. (2013). Building on the positive in children's lives: a co-participatory study on the construction of children's sense of agency. Early Child Development and Care, 184(2), 211-229. doi:10.1080/03004430.2013.778253

Levin, D. (2013). Beyond remote-controlled childhood: Teaching young children in the media age. Washington, DC: NAEYC.

Ministry of Education, Culture, Sports, Science, and Technology. (2008). Course of study for kindergarten. Retrieved from: http://www.mext.go.jp/english/elsec/1303755.html

Ministry of Education Republic of Korea. (2015). Teachers' guidebook for Nuri curriculum. Retrieved From http://www.moe.go.kr/web/100062/ko/board/view.do?bbsId=315\&bo $\operatorname{ardSeq}=58557$

National Council of Accreditation for Teacher Education. (2014). What makes a teacher effective? Retrieved from: http://www.ncate.org/Public/Research/Reports/TeacherPreparation\%2 0Research/WhatMakesateacherEffective/tabid/361/Default.aspx

Oishi, C. (2010). Photo projective method as a tool for expressing one's identity. Bulletin of Tokyo Women's College of Physical Education, 45, 131-141.

Park, E., Jang, M., \& Park, S. (2016). Early childhood education policies in Korea: Advances in theory and practice. In H. Lin, E. Park, and J. 
Chen (Eds.). Early childhood policies in Asia and Pacific (pp. 87107). Singapore: Springer.

Park, S., \& Park, E. (2014). Text network analysis of national kindergarten curriculum focusing on play: From the $1^{\text {st }}$ national kindergarten curriculum to Nuri curriculum. International Journal of Child Care and Education Policy, 8(1), 12-21.

Phelan, S., \& Kinsella, E. (2011). Photo elicitation interview methods and research with children. Qualitative Researching: Living Research, 5, 125-134. 10.3928/00220124-20110823-04

Pink, S. (2013). Doing visual ethnography (3rd ed). London, UK: Sage.

Ramazan, A., Ozdemir, A., \& Beceren, B. (2012). Evaluation of play from private and public pre-school children's point of view. Social and Behavioral Sciences, 46, 2852-2856.

doi:10.1016/j.sbspro.2012.05.576

Ray, J., \& Smith, A. (2011). Using photographs to research organizations:

Evidence, considerations, and application in a field study.

Organizational Research Methods, 15(2), 288-315.

doi:10.1177/1094428111431110

Roopnarine, J. (2015). Play as culturally situated: Diverse perspectives on its meaning and significance. In J. Roopnarine, M. Parre, J. Johnson, \& D. Kuschner (Eds.), International perspectives on children's play (pp. 1-7). New York: McGraw Hill Education.

Russell, J. (2011). From child's garden's academic press: The role of shifting institutional logics in redefining kindergarten education. American Educational Research Journal, 34(3), 195-201. doi:10.3102/0002831210372135

Sairanen, H., \& Kumpulainen, K. (2014). A visual narrative inquiry into children's sense of agency in preschool and 1st grade. International Journal of Educational Psychology, 3(2), 141-174. doi:10.4471/ijep.2014.09

Teramoto, K., \& Ohnishi, K. (1995). Kodomo wa mijikana sekai o do kanjiteiruka [How do children feel about their close environment?]. Aichi Kyouiku Daigaku Kenkyuu Houkoku, 44, 101-117.

Thompson, S., \& Williams, K. (2009). Telling stories with photo essays. Thousand Oaks, CA: Corwin. 
66 Izumi-Taylor et al.-Kindergartners' Perspectives of Play

Wiltz, N., \& Klein, E. (2001). What do you do in child care? Children's perceptions of high and low quality classrooms. Early Childhood Research Quarterly, 16, 209-236.

Wing, L. (1995). Play is not the work of the child: Young children's perspectives of work and play. Early Childhood Research Quarterly, $10,223-247$.

Satomi Izumi-Taylor is a professor of early childhood education and the Youth Services program coordinator with the Department of Instruction and Curriculum Leadership at the University of Memphis in the United States.

Yeon Sun (Ellie) Ro is the director of Institute of Early Global Education in the United States and the invited visiting professor at Sung Kyun Kwan university in Seoul, Korea.

Jihee Han is a principal of Eui-Myung kindergarten and adjunct professor of Chung-Ang university in Seoul, Korea.

Yoko Ito is a professor of the education faculty at Chiba university in Chiba, Japan. Her research interests include cross-cultural studies, home economics, and teacher education.

Contact Address: 400C Ball Hall University of MemphisMemphis, TN 38152 sitaylor@memphis.edu 